\title{
One-Point Cellulose Adsorbents for Water Purification
}

\author{
Azeh Yakubu, Yohanna Bello Paiko, and Gimba Alfred \\ Department of Chemistry, Ibrahim Badamasi Babangida University, P. M. B. 11, Lapai, Niger State, \\ Nigeria \\ yakubuazeh@gmail.com; yohanpaiks234@yahoo.com; azehy@ibbu.edu.ng; gimbaalfred@yahoo.com
}

\begin{abstract}
The protection of our environment from pollution by various industrial wastewater discharges is of great importance that each Industry treats its effluent to meet acceptable limit/design means to reclaim water from industrial effluents for re-use. The study aimed at reclaiming water from wastewater by assessing the performance of two cellulose adsorbents using the fixed-bed column method to treat pharmaceutical/metal wastewater. The study was carried out by determining the physico-chemical and microbiological parameters of wastewater quality before and after treatment using fixed-bed column. Effluent samples were collected and analyzed according to standard methods.

The range of percentage reduction in pollution load with respect to treatment time: 30, 120, 360 and 1440 min was 45-52\%, 55-64\%, 31-43, 25- 45\%, 41- 44\%, 55-73\%, 48- 51\%, 48-54\%, 56-71\% 13-31\%, 45-52\%, 47-67\% from the metal effluent using nanocellulose adsorbent while 14-24\%, 18-23\%, 4-10\%, 28-46\%, 16$20 \%, 24-42 \%, 14-32 \%, 42-57 \%, 32-52 \%, 36-47 \%, 37-56 \%, 8-53 \%$ from the pharmaceutical effluent using oxidized cellulose adsorbent for colour, turbidity, conductivity, total hardness, Nitrite, Phosphate, Ammonia, Biochemical Oxygen Demand, Chemical Oxygen Demand, total solids, total suspended solids and total dissolved solids respectively. Up to $99.9 \%$ was achieved by the adsorbents in the removal of biological contaminants. The study concluded that the celluloses adsorbents showed promising potentials as one-point adsorbent that can be used for water reclamation from wastewater by its ability to remediate both physico-chemical and bacteriological contaminants.
\end{abstract}

$\underline{\text { Key words: }}$ Bioadsorbent, Nanocellulose, Oxidized cellulose, Wastewater Purification

\section{Introduction}

Water is one of the most important natural resources of the world and plays a vital role in the development of communities. Quantity and the quality of drinking water/water for agricultural, industrial and domestic uses are critical for human growth and development. Water pollution is any contamination or change in the quality of water through contact with chemical, physical and biological elements with harmful effect [1]Nikoladze et al., (1994) and emerging contaminants [2]Davis and Cornell, (2008), resulting from human activities [3]Goel, (2006). People drinking contaminated water may experience diseases such as; typhoid, dysentery and cholera, among others [4](Wells, 1977). There are disease causing agents such as bacteria, viruses, protozoa and parasitic worms that enters sewage systems, untreated waste and oxygen-demanding wastes can be decomposed by oxygen-requiring bacteria and 
thus pollute water systems. Some pollutants may be toxic metals, acids or salts, microbial, organic matter, organic compounds, suspended solids etc of which when present in large quantities can make water unfit for drinking and can cause the death of aquatic life [5, 6](Hammer, 1977; Revenga and Mock, (2001). These components are either in solution or as particulate matter and can have bio-cumulative, persistent and synergetic characteristics affecting ecosystem, health and function, food production, human health and general well being [7](Corcoran et al., 2010).

The United States Environmental Protection Agency has defined effluent as wastewater (treated or untreated) that flows out of a treatment plant, sewer, or industrial outfall refers to wastes discharged into surface waters [8](USEPA, 2006). Pharmaceutical effluents are wastes generated by pharmaceutical industries during drug manufacturing. This industry suffers from inadequate effluent treatment due to the presence of recalcitrant substances. Important pollution index of industrial wastewaters are the oxygen function measured in terms of Chemical Oxygen Demand (COD), and Biological Oxygen Demand (BOD), while the nutrient status of wastewater is measured in terms of nitrogen and phosphorus. In addition, important water quality parameters include $\mathrm{pH}$, temperature and total suspended solids [9](Ezenobi and Okpokwasili, 2004). Industrial effluents are characterized by their abnormal turbidity, conductivity, chemical oxygen demand (COD); total suspended solids (TSS) and total hardness. In most developing countries, industries dispose their effluents without being properly treated. High levels of pollutants in river water causes an increase in Biological Oxygen Demand (BOD), Chemical Oxygen Demand (COD), Total Dissolved Solids (TDS), Total Suspended Solids (TSS), metals such as Cd, Cr, Ni and $\mathrm{Pb}$ and faecal coliforms and hence, make such water unsuitable for drinking, irrigation purposes and aquatic life.

Different technologies for treating wastewaters have been documented [10, 11](Woodard, 2001; Cheremisinoff, 2002). For effective treatment, combination of methods has been employed based on specific needs. However, some of these methods are either economically unfavourable or technically complicated and these make them difficult to be used in practice. According to literature reports [12, 13, 14](Dabrowski et al., 2005; Fierro et al., 2008; Pan et al., 2008), adsorption process using activated carbon is efficient for achieving high water purification in industrial processes. It is one of the best control technology available [15](Derbyshire et al., 2001). However, it attracts heavy cost due to the use of expensive and non-renewable material such as coal. In order to decrease the cost of treatment and expand its use in water treatment, attempts have been made to find low-cost adsorbents, using waste materials of cellulose origin [16](Dias et al., 2007). Cellulose is an effective and reliable biomaterial for removing contaminants [17](Aeppli and Dyer-Smith, 1999) due to its rich functional surface chemistry, which allows tailoring for specific applications [18](Robert and Mazzoni, 2008). Taste, odour and colour control are major problems difficult to overcome in water purification. Cellulose has great abilities to remove tastes and odour in water, which is a remarkable improvement in water purification [19](Dvorak and Skipton, 2008).

The study aimed at analysing the quality parameters of effluents from metal and pharmaceutical industries. Two adsorbents were used and these are: Nanocellulose produced by hydrolysis of microcrystalline cellulose using mineral acid and oxidized cellulose from Vitellaria Paradoxa flakes were used as adsorbents in a packed fixed-bed column for the continuous removal of physico-chemical and microbiological contaminants in the effluents of pharmaceutical and metal processing industry. 
Azeh Yakubu, Yohanna Bello Paiko, and Gimba Alfred; One-Point Cellulose Adsorbents for Water Purification. Journal of Biomedical Engineering and Medical Imaging, Volume 6, No 4, Aug (2019), pp 1-15

\section{Experimental Works}

\subsection{Materials and Methods}

All the chemicals used for the synthesis of nanocellulose and oxidized cellulose were of analytical grade and obtained from BDH Chemicals Ltd., (Poole, England). They were used without any further purification and these include cellulose, wood dust and acetic acid, hexane, ethanol, $\mathrm{H} 3 \mathrm{PO} 4, \mathrm{NaOH}$ and hypochlorite solution were obtained from BDH Chemicals. Deionized (DI) water was prepared from double-distilled water by passing through a deionizer.

\subsection{Synthesis and Purification of Cellulose Nanocrystals}

The preparation of cellulose nanocrystals followed the procedures described by [20].

\subsection{Removal of Wood Extractives from Wood Dust}

Thirty gram (30 g) of wood-dust was extracted with a mixture of hexane-ethanol 2:1 (v/v) for $3 \mathrm{~h}$ [21]. After extraction, samples were oven dry at 105 oC for $1 \mathrm{~h}$. delignification process was achieved by the addition of $100 \mathrm{~mL}$ (3.5\%) hypochlorite solution to the extracted wood-dust in a $500 \mathrm{~cm} 3$ beaker followed by the addition of $10 \mathrm{~mL}$ of acetic acid drop-wise and heated for $3 \mathrm{~h}$. The procedure was repeated six times to remove lignin and residual extractives according to [22].

\subsection{Isolation of Cellulose from Wood Dust}

Ten gram (10 g) of oven-dry extracted wood-dust sample was treated with $100 \mathrm{~mL}$ of $10 \% \mathrm{KOH}$ and heated for $1 \mathrm{~h}$. at $80 \mathrm{oC}$. The process was repeated until the product became white. The white insoluble residue was treated with $40 \mathrm{~mL}(3.5 \%)$ solution of hypochlorite with few drops of acetic acid at 80 oC, filtered and thoroughly rinsed with deionized (DI) water until the $\mathrm{pH}$ of the washed water was neutral, disintegrated and air-dried. The product was characterized using FT-IR, SEM and TGA [21-23].

\subsection{Water Samples Collection}

Industrial effluents were collected from two different industries located in Nigeria. Effluent collected from a pharmaceutical industry where it was discharge into pit storage before it finally goes into the central dam. Samples were collected from the metal making industry at the point of discharge into the dam. The two samples were analyzed for the physico-chemical parameters including turbidity, odour, colour, $\mathrm{pH}$, conductivity, hardness, nitrite, sulphate, TDS, and microbiological parameters were determined within 24 $\mathrm{h}$ of sample collection using standard methods [24-27].

\subsection{Microbial Effluents Analysis}

A number of biochemical tests were performed for the isolation, characterization and identification of bacterial isolates using standard methods [28-30].

\subsubsection{Column Experiment}

A fixed bed column study was carried out using $50 \mathrm{~mL}$ burette with an internal diameter of $1 \mathrm{~cm}$ and 69.6 $\mathrm{cm}$ by length. Oxidized cellulose and Nanocellulose with $3.81 \mathrm{~g}$ and $6.0 \mathrm{~g}$ as adsorbent mass were weighed and used in the study. A fine silica gel was packed at the bottom of the column followed by introducing 3.81 or $6.0 \mathrm{~g}$ of the nanocellulose or oxidized cellulose adsorbent then, cotton wool was placed at the top of the packed adsorbent in the column to prevent floating. Bed height of $12.3 \mathrm{~cm}$ and $13.3 \mathrm{~cm}$ were used 
for the oxidized and nanocellulose adsorbents respectively. The column was placed at a higher elevation so that the effluent could be introduced into the column by a downward flow at a constant rate of $6 \mathrm{~mL}$ per minute with a maximum solvent head of $4 \mathrm{~cm}$ maintained. Filtrate was collected at different time intervals of $10-1440$ min using plastic sample bottles and analyzed for the residual physicochemical and microbiological parameters.

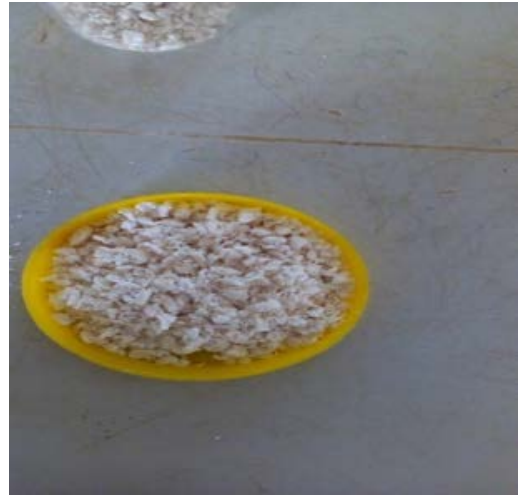

A

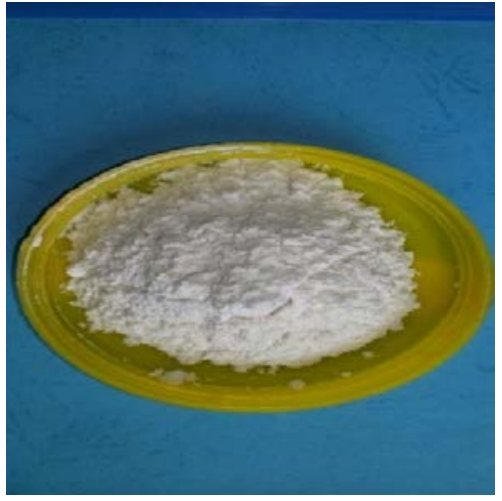

b

Plate. I: (a) Oxidized cellulose (b) Nanocellulose

\section{Results and Discussion}

\subsection{Physico-chemical and Microbiological Parameters}

Physico-chemical parameters and microbial activities were carried out for both pharmaceutical and metal industry effluents in triplicates. Six samples were analyzed on each effluent. The total heterotrophic bacterial $\left(X_{\mathrm{OHO}}\right)$ count was $3.0 \times 10^{4} \mathrm{cfu} / \mathrm{mL}$ in the pharmaceutical effluent while $2.0 \times 10^{3} \mathrm{cfu} / \mathrm{mL}$ was recorded in the metal effluent. The physico-chemical parameters including taste, odour, $\mathrm{pH}$, temperature, turbidity, conductivity, total suspended solids $\left(X_{\mathrm{TSS}}\right)$, total dissolved solids ( $\left.X_{\mathrm{TDS}}\right)$, biological oxygen demand (BOD), chemical oxygen demand (COD), and total solids (TS) of the water samples are presented in Table 7 and 10. From the Tables 7 and 10, it can be seen that after treatment in the column packed with nanocellulose, the physico-chemical parameters of the effluents were improved. The $\mathrm{pH}$, turbidity, conductivity, colour and total hardness of the treated effluent from the pharmaceutical industry were in the range of 5.39-6.70 (pH), 13.62-11.65 NTU (Turbidity); 124.7-112.84 $\mathrm{S} / \mathrm{cm}$ (Conductivity); 10.11-7.65 $\mathrm{H}$ (Colour) and $37.46-27.18 \mathrm{mg} / \mathrm{L}$ (TDS) while the physico-chemical parameters of the metal industrial effluent ranged from 6.55-6.66 $(\mathrm{pH}) ; 19.56-7.01 \mathrm{NTU}$ (Turbidity); 256.80-125.41 $\mu \mathrm{S} / \mathrm{cm} ; 15.17-7.22 \mathrm{H}$ (Colour) and 35.52-19.41 mg/L (TDS) respectively.

The mean and standard deviation were also calculated using the formulas below:

$$
\begin{gathered}
\bar{x}=\frac{x_{1+x_{2+}+x_{3+\cdots} x_{n-1}+x_{n}}}{n} \\
\mathrm{SD}=\sqrt{\frac{\left(x_{1-\bar{x}}\right)^{2}+\left(x_{2-\bar{x}}\right)^{2}+\cdots\left(x_{n-\bar{x}}\right)^{2}}{n-1}}
\end{gathered}
$$

$\operatorname{Variance}(\sigma)=S^{2}$ 
Azeh Yakubu, Yohanna Bello Paiko, and Gimba Alfred; One-Point Cellulose Adsorbents for Water Purification. Journal of Biomedical Engineering and Medical Imaging, Volume 6, No 4, Aug (2019), pp 1-15

Table 1: Mean and Error Analysis of Oxidized Cellulose-treated and Raw Effluent from Pharmaceutical Industry

\begin{tabular}{ccccccc}
\hline $\begin{array}{c}\text { Sample/elution } \\
\text { time }\end{array}$ & Mean & Absolute Error & $\begin{array}{c}\text { Relative } \\
\text { Error }\end{array}$ & $\begin{array}{c}\text { \% Relative } \\
\text { Error }\end{array}$ & $\begin{array}{c}\text { Standard } \\
\text { Deviation }\end{array}$ & $\begin{array}{c}\text { Variance } \\
(\sigma)\end{array}$ \\
\hline RAW & $3.03 \times 10^{3}$ & Nil & Nil & Nil & $\pm 1.53 \times 10^{3}$ & $2.3409 \times 10^{6}$ \\
$30 \mathrm{~min}$ & $1.47 \times 10^{2}$ & -2883 & -0.95 & -95 & $\pm 5.79 \times 10^{2}$ & $3.35241 \times 10^{5}$ \\
$120 \mathrm{~min}$ & $1.03 \times 10^{2}$ & -2927 & -0.96 & -96 & $\pm 5.79 \times 10^{2}$ & $3.35241 \times 10^{5}$ \\
$360 \mathrm{~min}$ & $1.0 \times 10^{0}$ & -3029 & -0.99 & -99 & $\pm 1.0 \times 10^{1}$ & 100 \\
$1440 \mathrm{~min}$ & $3.67 \times 10^{2}$ & -2663 & -0.87 & -87 & $\pm 5.79 \times 10^{2}$ & $3.35241 \times 10^{5}$ \\
\hline
\end{tabular}

Table 2: Mean and Error Analysis of Nanocellulose-treated and Raw Effluent from Metal Industry

\begin{tabular}{|c|c|c|c|c|c|c|}
\hline $\begin{array}{c}\text { Sample/elution } \\
\text { time }\end{array}$ & Mean & $\begin{array}{c}\text { Absolute } \\
\text { Error }\end{array}$ & $\begin{array}{l}\text { Relative } \\
\text { Error }\end{array}$ & $\begin{array}{c}\text { \% Relative } \\
\text { Error }\end{array}$ & $\begin{array}{l}\text { Standard } \\
\text { Deviation }\end{array}$ & $\begin{array}{c}\text { Variance } \\
(\sigma)\end{array}$ \\
\hline $30 \mathrm{~min}$ & $7 \times 10^{\circ}$ & -2163 & -0.997 & -99.7 & $\pm 1.0 \times 10^{1}$ & 100 \\
\hline $360 \mathrm{~min}$ & $4.33 \times 10^{2}$ & -2165.67 & -0.998 & -99.8 & $\pm 1.53 \times 10^{2}$ & $2.3409 \times 10^{6}$ \\
\hline $1440 \mathrm{~min}$ & $3.33 \times 10^{2}$ & -2166.67 & -0.999 & -99.9 & $\pm 2.31 \times 10^{2}$ & $5.3361 \times 10^{4}$ \\
\hline
\end{tabular}

Table 3: Removal Efficiency of Organisms from Pharmaceutical and Metal Industrial Effluents

\begin{tabular}{ccc}
\hline Time (min) & $\begin{array}{c}\text { Pharm } \\
(\%)\end{array}$ & Metal (\%) \\
\hline 30 & 99.50 & 99.68 \\
120 & 99.70 & 99.78 \\
360 & 99.97 & 99.80 \\
1440 & 99.97 & 99.85 \\
\hline
\end{tabular}
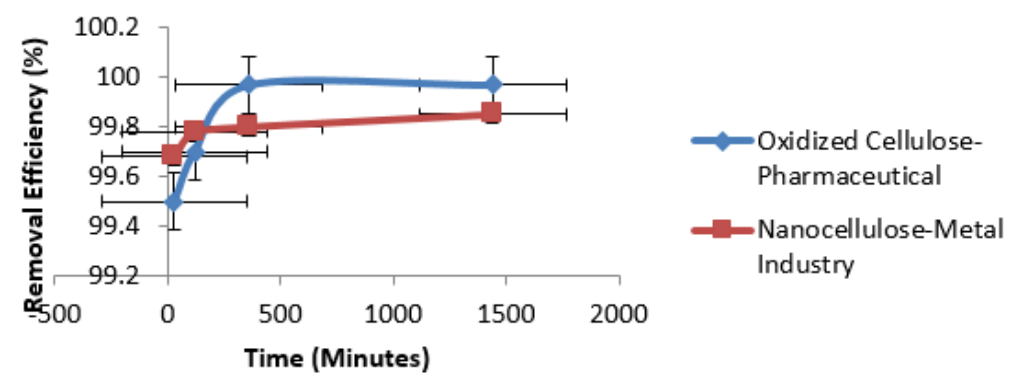

Figure 1: Plot of Organisms removed from the Pharmaceutical and Metal Industrial Effluents against Time 


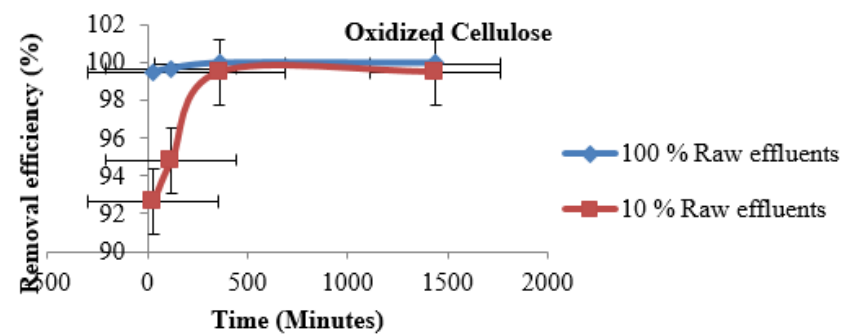

Fig 2: Removal efficiency of Organisms from the Pharmaceutical Industrial Effluent against Time

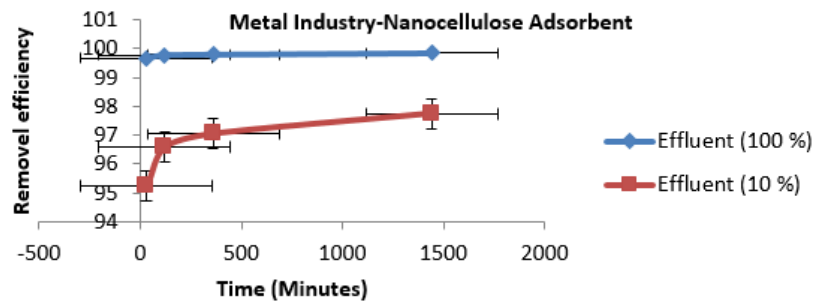

Fig 3: Removal efficiency of Organisms from the Metal-Industrial Effluent against Time

The structural morphology of the nanocellulose and oxidized cellulose before and after used as contaminant adsorbents was examined using Scanning Electron Microscopy and the SEM images are as shown in (Plate II). The SEM images confirms that the synthesized nanocellulose consist particles with different shapes of ranging from irregular to individual rod-like shaped nanocellulose. Whereas, after the treatment of the effluents, the SEM images the used nanocellulose confirms that the morphology of the nanocellulose changed from the irregular and individual rod-like shaped to large clusters, which has been attributed to the formation of hydrogen bond network with water molecules and the biological contaminants. On the other hand, the SEM images of the oxidized cellulose reveals the presence of filamentous cellulose strands with less compact arrangement, compared to its morphology after it was used for effluent treatment. One could see that the surface of the filamentous network of the cellulose fibres was smoother, implying that some interactions had occurred on the surface during adsorption. The cellulose fibrils were randomly oriented similar to the findings by [31].

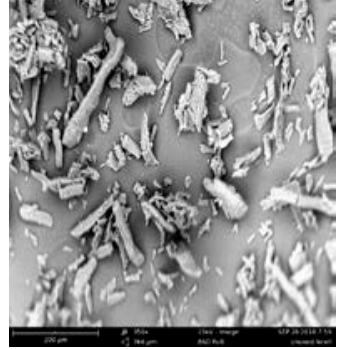

$\mathrm{a}$

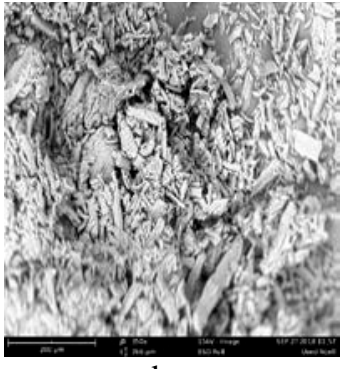

b

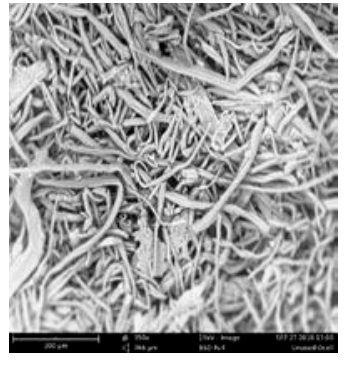

C

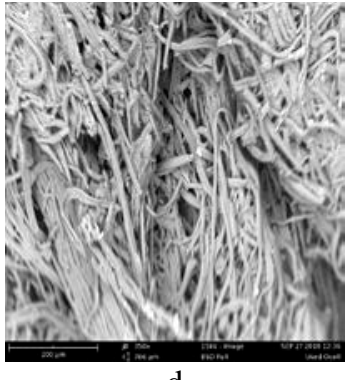

d

Plate II: Nanocellulose before use (a), Nanocellulose after use (b), Oxidized Cellulose before use (c), and Oxidized Cellulose after use (d)

The percent adsorption (\%) was calculated using the equation

$$
\% \text { adsorption }=\frac{C_{i}-C_{f}}{C_{i}} \times 100
$$


Azeh Yakubu, Yohanna Bello Paiko, and Gimba Alfred; One-Point Cellulose Adsorbents for Water Purification. Journal of Biomedical Engineering and Medical Imaging, Volume 6, No 4, Aug (2019), pp 1-15

The plots for the removal efficiency (Figure 1) shows that the removal efficiency increased with increasing treatment time of the effluents in the column from 30, 120, 360 and 1440 min. Both adsorbents were effective in removing micro-organisms in the effluents and with high removal efficiency recorded for both adsorbents. As shown in (Table 3), over $99 \%$ of the micro-organisms were removed within the time frame used for the treatment of effluents using a fix-bed column. These value was in agreement with the Geneva report by the [32], which stipulates that the removal efficiency for the microbiological contaminants in water treatment must reach $99.99 \%$ for both bacteria and viruses. Figures $\mathbf{2}$ and $\mathbf{3}$ were plotted in order to establish the correlation between the concentrations of micro-organisms in the raw and the $10 \%$ solution of the raw effluent samples. It can be seen from the plots of the effluent samples against time that the number of organisms removed was concentration dependant. This was expected since the higher the concentration the higher the number of micro-organisms available to be trapped by the adsorbents.

Table 4: Bacteria Colony Count in Pharmaceutical and Metal Effluents after Column Treatment

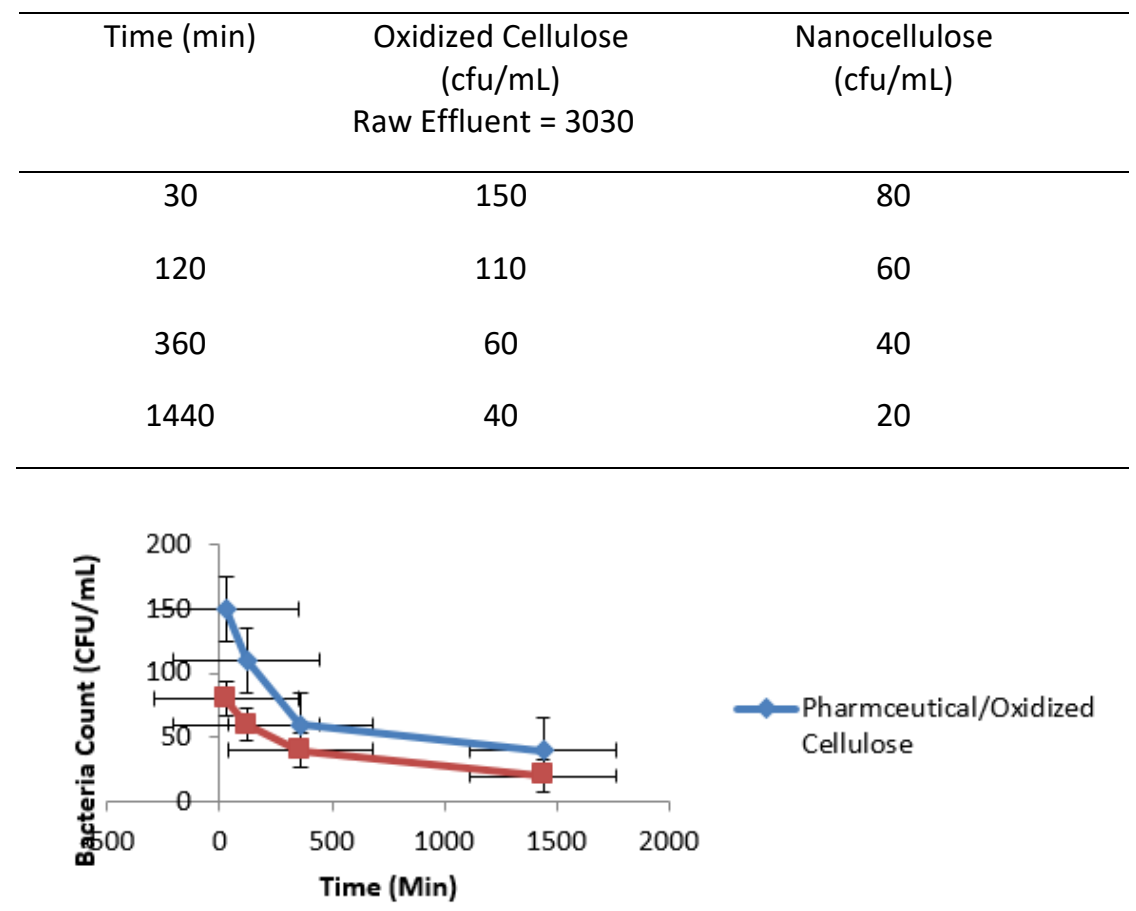

Figure 4: Plot of bacteria colony count (cfu/mL) after treatment

The above plot shows bacteria count against treatment time in the column (Figure 4). It is seen that the downward flow of effluents through the adsorbents packed bed at different time intervals of 30,120, 360 and $1440 \mathrm{~min}$, showed that the $\mathrm{cfu} / \mathrm{mL}$ of the organisms present in the raw effluent from the metal industry decreased from $2.17 \times 10^{3} \mathrm{cfu} / \mathrm{mL}$ to $2.0 \times 10^{1} \mathrm{cfu} / \mathrm{mL}$ after $1440 \mathrm{~min}$ of treatment using column packed with nanocellulose while $3.03 \times 10^{3} \mathrm{cfu} / \mathrm{mL}$ from pharmaceutical decreased to $4.0 \times 10^{1} \mathrm{cfu} / \mathrm{mL}$ after the effluent was allowed to flow for 1440 min through a column packed with oxidized cellulose as adsorbent. This implies that both celluloses can be used as adsorbents for the removal of biological contaminants in wastewater/water system. The nanocellulose adsorbent proved to be more effective in removing micro-organisms than the oxidized cellulose. This is attributable to the surface area and it large number of hydroxyl functional groups on its surface [33-34]. 
Journal of Biomedical Engineming and Medical Imaging, Volume 6, No 4, August 2019

\subsection{Microbial Count, Characterization and Identification of Microorganisms in Metal Industrial Effluent}

Table 5: Bacterial Colony Count, Characterization and Identification of Microorganisms in Kamwil Industrial Effluents before Treatment

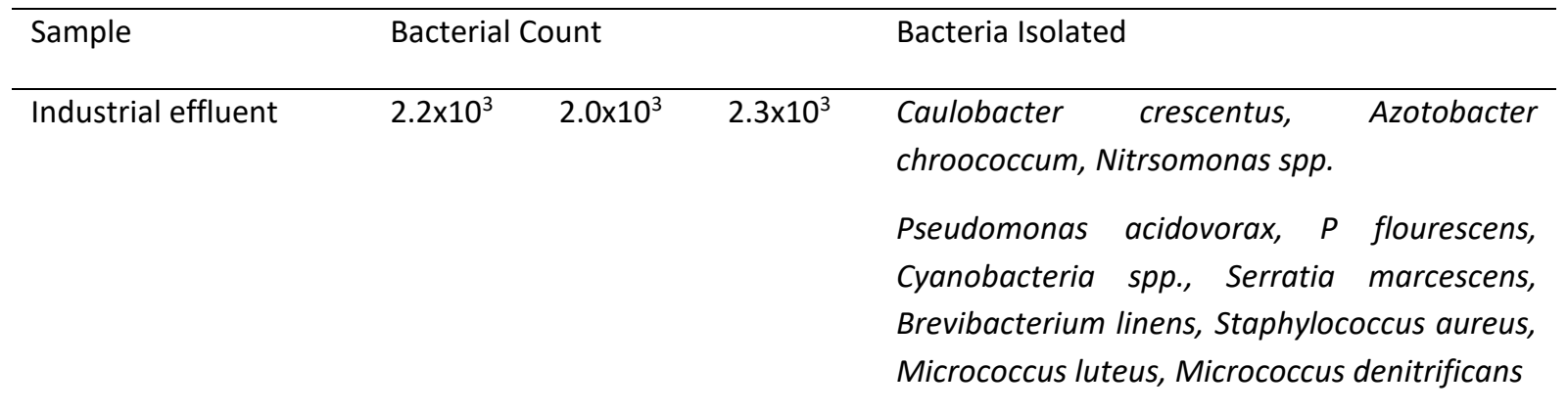

Table 6: Bacterial Colony Count, Characterization and Identification of Microorganisms after Treatment of Effluents using Nanocellulose Adsorbent

\begin{tabular}{|c|c|c|c|c|}
\hline Time & \multicolumn{3}{|c|}{ Bacterial Count } & Bacterial Isolated \\
\hline 30 & $0.8 \times 10^{1}$ & $0.6 \times 10^{1}$ & $0.7 \times 10^{1}$ & Serratia marcescens, Proteus vulgaris \\
\hline 120 & $0.6 \times 10^{1}$ & $0.5 \times 10^{1}$ & $0.4 \times 10^{1}$ & Pseudomonas acidovorax, P. Flourescens \\
\hline 360 & $0.4 \times 10^{1}$ & $0.3 \times 10^{1}$ & $0.6 \times 10^{1}$ & Cyanobacteria spp \\
\hline 1440 & $0.2 \times 10^{1}$ & $0.2 \times 10^{1}$ & $0.3 \times 10^{1}$ & Brevibacterium linens \\
\hline
\end{tabular}

Table 7: Physicochemical Properties of Untreated Effluent and Treated Metal Industrial Effluent

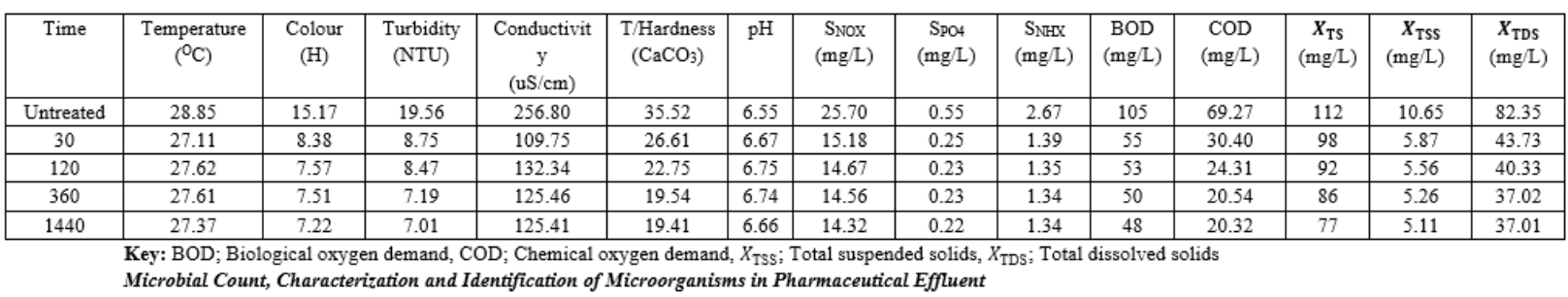

Table 8: Bacterial Colony Count, Characterization and Identification of Microorganisms in Raw Metal Industrial Effluents

\begin{tabular}{|c|c|c|c|c|}
\hline Sample & & teria Coun & & Bacteria Isolated \\
\hline Industrial & $3.2 \times 10^{4}$ & $2.9 \times 10^{4}$ & $3.0 x$ & Brevibacterium linens, Staphylococcus \\
\hline
\end{tabular}


Azeh Yakubu, Yohanna Bello Paiko, and Gimba Alfred; One-Point Cellulose Adsorbents for Water Purification. Journal of Biomedical Engineering and Medical Imaging, Volume 6, No 4, Aug (2019), pp 1-15

Table 9: Bacterial Colony Count, Characterization and Identification of Microorganisms after Treatment of Pharmaceutical Effluents using Oxidized Cellulose

\begin{tabular}{ccccl}
\hline $\begin{array}{c}\text { Elution } \\
\text { Time (min) }\end{array}$ & \multicolumn{2}{c}{ Bacteria Count } & \multicolumn{1}{c}{ Bacteria Isolated } \\
\hline 30 & $1.5 \times 10^{2}$ & $1.4 \times 10^{2}$ & $1.5 \times 10^{2}$ & $\begin{array}{l}\text { Brevibacterium linens, Staphylococcus aureus, Micrococcus luteus, } \\
\text { Micrococcus denitrificans }\end{array}$ \\
120 & $1.1 \times 10^{2}$ & $1.0 \times 10^{2}$ & $1.0 \times 10^{2}$ & $\begin{array}{l}\text { Proteus vulgaris, Klebsiella oxytoca } \\
360\end{array}$ \\
1440 & $0.6 \times 10^{2}$ & $0.5 \times 10^{2}$ & $0.4 \times 10^{2}$ & Pseudomonas acidovorax, P. Flourescens \\
& $0.4 \times 10^{2}$ & $0.3 \times 10^{2}$ & $0.4 \times 10^{2}$ & Cyanobacteria spp
\end{tabular}

Table 10: Physicochemical Properties of Untreated and Treated Pharmaceutical Industrial Effluent

\begin{tabular}{|c|c|c|c|c|c|c|c|c|c|c|c|c|c|c|}
\hline Sample/Time & $\begin{array}{c}\text { Temperature } \\
\left({ }^{\circ} \mathrm{C}\right)\end{array}$ & $\begin{array}{l}\text { Colour } \\
(\mathrm{H})\end{array}$ & $\begin{array}{l}\text { Turbidity } \\
\text { (NTU) }\end{array}$ & $\begin{array}{l}\text { Conductivity } \\
(\mu \mathrm{s} / \mathrm{Cm})\end{array}$ & $\begin{array}{c}\mathrm{T} / \text { Hardness } \\
\left(\mathrm{CaCO}_{3}\right)\end{array}$ & $\mathrm{Ph}$ & $\begin{array}{c}\mathrm{S}_{\mathrm{Nox}} \\
(\mathrm{mg} / \mathrm{L})\end{array}$ & $\begin{array}{c}\mathrm{SpO4} \\
(\mathrm{mg} / \mathrm{L})\end{array}$ & $\begin{array}{c}\mathrm{S}_{\mathrm{NHX}} \\
(\mathrm{mg} / \mathrm{L})\end{array}$ & $\begin{array}{l}\text { BOD } \\
(\mathrm{mg} / \mathrm{L})\end{array}$ & $\begin{array}{l}\mathrm{COD} \\
(\mathrm{mg} / \mathrm{L})\end{array}$ & $\begin{array}{c}X_{\mathrm{TS}} \\
(\mathrm{mg} / \mathrm{L})\end{array}$ & $\begin{array}{c}\boldsymbol{X}_{\mathrm{TSS}} \\
(\mathrm{mg} / \mathrm{L})\end{array}$ & $\begin{array}{c}\boldsymbol{X}_{\mathrm{TDS}} \\
(\mathrm{mg} / \mathrm{L})\end{array}$ \\
\hline Untreated & 28.20 & 10.11 & 13.62 & 124.7 & 37.46 & 5.39 & 19.40 & 0.38 & 1.80 & 65 & 28.05 & 282 & 11.5 & 85.71 \\
\hline 30 & 27.66 & 8.73 & 11.24 & 119.40 & 26.89 & 6.70 & 16.21 & 0.29 & 1.54 & 38 & 19.05 & 180 & 7.21 & 79.32 \\
\hline 360 & 27.54 & 7.79 & 10.84 & 117.38 & 27.91 & 6.54 & 15.98 & 0.25 & 1.52 & 39 & 15.67 & 184 & 7.28 & 78.42 \\
\hline 1440 & 27.61 & 7.65 & 11.65 & 112.84 & 27.18 & 6.70 & 15.50 & 0.22 & 1.63 & 36 & 15.74 & 180 & 8.11 & 81.37 \\
\hline
\end{tabular}

The study demonstrated that the effluents collected from the process water of two industries met certain internationally or locally acceptable standards recommended for wastewater discharge. However, some deviations from the water quality guidelines $[35,36,37,38,39]$ were observed. The heterotrophic bacteria count recorded in the untreated effluent exceeded the standard permissible limit of $1.0 \times 10^{2}$ $\mathrm{cfu} / \mathrm{mL}$ for drinking water quality [35, 40,41-42]. This implies that the effluents discharge had excessive presence of micro-organisms. The average values of the untreated pharmaceutical effluents and after 30 min treatment of effluents sample were $3.2 \times 10^{4}, 2.9 \times 10^{4}$ and $3.0 \times 10^{4} \mathrm{cfu} / \mathrm{mL}$ with an average value of $3.03 \times 10^{4} \mathrm{cfu} / \mathrm{mL}$ (Untreated effluent) and $1.5 \times 10^{2}, 1.4 \times 10^{4}$ and $1.5 \times 10^{2} \mathrm{cfu} / \mathrm{mL}$ with the average value of $1.47 \times 10^{2} \mathrm{cfu} / \mathrm{mL}$ for the $30 \mathrm{~min}$ treatment in the column. The values of the $\mathrm{cfu} / \mathrm{mL}$ obtained after 30 min treatment with the oxidized cellulose far exceeded the World Health Organization WHO permissible limit $[35,41]$. In the other hand, effluent collected from metal industry had $2.2 \times 10^{3}, 2.0 \times 10^{3}$, and $2.3 \times$ $10^{3} \mathrm{cfu} / \mathrm{mL}$ with an average value of $2.17 \times 10^{3} \mathrm{cfu} / \mathrm{mL}$ as the initial concentration of microbes in the untreated effluent. It was observed that 120-1440 min treatment of both effluents in the column packed with different cellulose adsorbents gave best results, as the treated effluents collected and analyzed gave values which were within the permissible and/or below the permissible limit [35]. The results obtained for the effluent sample collected at a pharmaceutical industry were $1.1 \times 10^{2}, 1.0 \times 10^{2}$ and $1.0 \times 10^{2}$ $\mathrm{cfu} / \mathrm{mL}$ with an average of $1.03 \times 10^{2} \mathrm{cfu} / \mathrm{mL}(120 \mathrm{~min}) ; 0.6 \times 10^{2}, 0.5 \times 10^{2}$ and $0.4 \times 10^{2} \mathrm{cfu} / \mathrm{mL}$ with an average of $0.05 \times 10^{2} \mathrm{cfu} / \mathrm{mL}\left(360 \mathrm{~min}\right.$ ) and $0.4 \times 10^{2}, 0.3 \times 10^{4}$ and $0.4 \times 10^{2} \mathrm{cfu} / \mathrm{mL}$ with an average value of $0.37 \times 10^{4} \mathrm{cfu} / \mathrm{mL}(1440 \mathrm{~min})$. The treated effluent collected from the metal industry had the following values: $0.8 \times 10^{1}, 0.6 \times 10^{2}$ and $0.7 \times 10^{1} \mathrm{cfu} / \mathrm{mL}$ with an average value of $0.70 \times 10^{1} \mathrm{cfu} / \mathrm{mL}$ (30 min); 0.6 $\times 10^{1}, 0.5 \times 10^{1}$ and $0.4 \times 10^{1} \mathrm{cfu} / \mathrm{mL}$ with an average value of $0.50 \times 10^{1} \mathrm{cfu} / \mathrm{mL}(120 \mathrm{~min}) ; 0.4 \times 10^{1}, 0.3$ $\times 10^{1}$ and $0.6 \times 10^{1} \mathrm{cfu} / \mathrm{mL}$ with an average of $0.43 \times 10^{4} \mathrm{cfu} / \mathrm{mL}(360 \mathrm{~min})$ and $0.2 \times 10^{1}, 0.2 \times 10^{1}$ and 0.3 $\times 10^{1} \mathrm{cfu} / \mathrm{mL}$ with an average value of $0.23 \times 10^{4} \mathrm{cfu} / \mathrm{mL}(1440 \mathrm{~min})$. It is evident from the above results that after treatment of the effluents from both industries, the cellulose adsorbents showed good potential for the bioremediation of industrial effluents laden with biological contaminants to the level acceptable 
by $[35,40,41,43]$. However, the nanocellulose adsorbent proved to be a better one point adsorbent for the treatment of effluents. Many of the microorganisms enumerated in this study are some bacteria (Bacillus, Salmonella, Staphylococcus etc) known to cause water-borne infectious diseases. These pathogenic bacteria that infect the human intestine can come from the release of effluents from industry into the water bodies and their presence can cause diarrhea, nausea and vomiting [44].

The high number of bacteria count recorded in the effluent sample of the pharmaceutical industry was probably due to the use of metal salts and biopolymers, as binders in drug formulations and can serve as nutrients for the growth of microbes. None of the wastewater samples from both industries met the standards [35] for bacterial count in drinking water. However, after treatment, it met the maximum allowable limits $[35-36,45]$. The low $\mathrm{pH}$ value obtained from the pharmaceutical raw water sample could be attributed to the concentrated acid and base used for drug production and also detergent used to wash machine and apparatus which reduces the $\mathrm{pH}$ value. High level of turbidity was recorded in the metal industrial raw effluent than in the effluent from the pharmaceutical industry. The two cellulose adsorbents showed that they could remove colour in the effluents. This implies that the adsorbents have the potential for the adsorption of colouring matter in aqueous medium. This was in agreement with the report by [19] on the ability of cellulose to eliminate tastes and odour in water purification technologies. However, the maximum duration used for the treatment of effluent in the column could not reduce the colour/turbidity of the effluent to the allowable limits of 5 TCU and 1.5 NTU established by [36] within the time frame used for the treatment (Table 7 and 10). High turbidity has been associated with higher levels of disease causing microorganisms such bacteria and other parasites [46]. Consumers are reluctant to drink water, however safe, which has a yellowish to brown colour, and because of this revulsion any water that is coloured is very undesirable.

The conductivity values (Table 7 and 10) of the wastewater analyzed were within the permissible limit of $1000 \mu \mathrm{S} / \mathrm{cm}$ established by [35-38, 40]. However, conductivity values decreases with increasing adsorption time, which indicates that ions in the effluents were adsorbed. The conductivity value of the metal wastewater was high due to ionizable species in the wastewater whereas, the value in the pharmaceutical wastewater was low due to non-ionizable species [40]. Conductivity value is a function of the materials used by an industry. The conductivity values obtained in this study were similar to the findings by [47] and [48].

Total suspended solids (TSS) were low in the metal effluent. Column adsorption led to a decrease in TSS with increasing time (Table 7). This implies that the adsorbents remove suspended solid. The TDS in all the wastewater analyzed were within the limit of $500 \mathrm{mg} / \mathrm{L}$ for drinking water quality [32, 36-37, 45]. Column adsorption show that TDS decreased from 82.35 - $37.01 \mathrm{mg} / \mathrm{L}$, representing (55\%) of the dissolved solid removed in the pharmaceutical effluent while 10.65-5.11 m/L, representing (52\%) dissolved solid removed from the effluent from the metal industry.

Results in this study were indicative of the biological contamination, due to high heterotrophic bacterial colony counts, high percentage of bacteria such as Brevibacterium linens, Staphylococcus aureus, Micrococcus and luteus etc isolated in the wastewater from the two industries analyzed. Column adsorption using celluloses adsorbents removed different micro-organisms and physico-chemical parameters in the wastewater. This study will help tremendously in the planed wastewater reuse programme in Nigeria and other developing nations and the global community, where reclaimed 
Azeh Yakubu, Yohanna Bello Paiko, and Gimba Alfred; One-Point Cellulose Adsorbents for Water Purification. Journal of Biomedical Engineering and Medical Imaging, Volume 6, No 4, Aug (2019), pp 1-15

wastewater has different useful applications [49]. Pathogenic bacteria, viruses, protozoa, and cyanobacteria are known to affect human health. The Japanese regulations for bacteria levels in drinking water safety, requires that in $1 \mathrm{~mL}$ of test water, the number of colony of general bacteria is under 100 with no total coliforms [41]. The presence of cyanobacteria may be attributed to the levels of nitrogen and phosphorus in the wastewater similar to the findings by [41]. The performance of cellulose adsorbents in the analyses of other water quality parameters are expressed in term of percentage reduction in pollutant load as a function of time, 30, 120, 360 and $1440 \mathrm{~min}$ ): 25, 36, 45 and 45\%, 41, 43, 43 and 44\%, 55, 58, 60 and $73 \%, 48,49,50$ and 51\%, 48, 50, 52 and 54\%, 56, 65, 70 and $71 \%$ 13, 18, 23 and 31\%, from the metal effluent by the nanocellulose adsorbent while $28,32,37$ and $46 \%, 16,17,18$ and $20 \%, 24,32$, 34 and $42 \%, 14,17,27$ and $32 \%, 42,45,51$ and $57 \%, 32,39,44$ and $52 \%, 36,36,38$ and $47 \%$, from the pharmaceutical effluent using oxidized cellulose adsorbent for total hardness, Nitrite, Phosphate, Ammonia, BOD, COD and total solids respectively.

\section{Conclusion}

The celluloses adsorbents show high performance in terms of the sorption of both physico-chemical and bacteriological contaminants in the industrial wastewater analyzed. $99.98 \%$ efficiency was achieved in term of reduction in bacteriological contaminants, which was in agreement with NAFDAC, WHO and Japan permissible level for both bacteria and viruses. The $\mathrm{pH}$, turbidity, colour, COD, BOD and other parameters evaluated were observed to decrease with increasing treatment time. Out of a total number of eleven (11) micro-organisms determined in the pharmaceutical wastewater, only one organism was determined after adsorption using oxidized cellulose at $1440 \mathrm{~min}$. In the other hand, nine (9) organisms were detected in the metal wastewater of which only one organism was detected after adsorption using nanocellulose at $1440 \mathrm{~min}$. The results indicate that functionalized celluloses as adsorbents may be used to re-claim water from wastewater for various uses.

\section{ACKNOWLEDGEMENTS}

The authors wish to acknowledge IBB University IBR TETfund Research 2015-2016 Intervention awarded in 2017, for the financial support, which ensured the success of this research work.

\section{REFERENCES}

[1] Nikoladze, E. D., Nits, M. and Kastalsky, Water treatment for public and industrial supply. 1994. 1416.

[2] Davis, M. L. and D.A. Cornwell, Introduction to environmental Engineering. $4^{\text {th }}$ ed2008. McGraw-Hill, N.Y.

[3] Goel, P. K.., Water pollution: Causes effect and control. New Age International, New Delhi. 2006.

[4] Wells, R.J., Water quality criteria and standard. Water. Pollut. Cont., 1977. 77: p. 25-30.

[5] Hammer, J. M., Water quality and pollution waste and water technology 2 nd ed1977. John Wiley and Sons, New-York; p. 143-168. 
[6] Revenga, C. and G. Mock, Dirty water: pollution problems persist, Earth Trends:Featured Topic, 2001. p.1-6.

[7] Corcoran, E., Nellemann, C., Baker, E., Bos, R., Osborn, D. and H. Savelli, 2010. Sick water? The central role of wastewater management in sustainable development. A rapid response assessment. United Nations Environment Programme, UN-HABITAT, GRID-Arendal.

[8] USEPA, 2006. United States Environmental Protection Agency. 2006-10-03.

[9] Ezenobi, N. O. and Okpokwasili, Bacterial flora and physico-chemical characteristics of hospital sewage in Port Harcourt City. Nigerian Journal of Microbiology, 2004. 18(1-2): p. 277-283.

[10] Woodard F. 2001. Industrial waste treatment handbook, by Butterworth-Heinemann Methods for treating wastewaters from industry. Chapter 8, pp. 335.

[11] Cheremisinoff, N. P., Handbook of water and wastewater treatment. Butterworth Heinemann. Boston, USA. 2002. p. 1-655.

[12] Dabrowski, A., Podkoscielny, P., Hubicki, Z. and M. Barczak, Adsorption of phenolic compounds by activated carbon-a critical review. Chemosphere, 2005. 58: 1049-1070.

[13] Fierro V., Torne-Fernandez V., Montane D. and A. Celzard, Microporous and Mesoporous Materials, 2008. 111, 276-284.

[14] Pan. B., Pan. Bi, Zhang. W., Zhang. Q., Zhang. Q. and S. Zheng, Adsorptive removal of phenol from aqueous phase by using a porous acrylic ester polymer. Journal of Hazardous Materials, 2008. 157(2-3): p. 293-299.

[15] Derbyshire F., Jagtoyen M., Andrews R., Rao A., Martin-Gullon I. and E. Grulke, Carbon materials in environmental applications. Marcel Decker, New York. 2001. p. 1-66.

[16] Dias J.M., Alvim-Ferraz M.C.M., Almeida M.F., Riverra-Urtella J. and M. Sanchez-Polo, Waste materials for activated carbon preparation and its use in aqueous-phase treatment: J. Environment. Manage. 2007. 85: 833-846.

[17] Aeppli, J. and P. Dyer-Smith, Ozone and Granular activated filtration, the solution to many problems, Ozonia Limited Duebendorf, Switzerland. 1999. p. 12.

[18] Robert, T. D. and A.F. Mazzoni, Water filtration TIEE Corporation, U.S.A 2008. p. 6-15.

[19] Dvorak, B. I. and S.O. Skipton, Drinking water treatment, Activated carbon filtration, University of Nebraska-Lincoln Extension, Institute of Agriculture and Natural Resources, Binco., 2008. 1: p. 2-4.

[20] Azeh, Y., Olatunji, G. A. and Adekola F. A. (2017). Synthesis and characterization of cellulose nanoparticles and its derivatives using a combination of spectro-analytical techniques. International Journal of Nanotechnology in Medicine \& Engineering, 2017. 2(6): p. 65-94. 
Azeh Yakubu, Yohanna Bello Paiko, and Gimba Alfred; One-Point Cellulose Adsorbents for Water Purification. Journal of Biomedical Engineering and Medical Imaging, Volume 6, No 4, Aug (2019), pp 1-15

[21] Azeh, Y Olatunji, G.A., Cheku, M. and P.A. Mamza, Acetylation of wood flour from four wood species grown in nigeria using vinegar and acetic anhydride. International Journal of Carbohydrate Chemistry, 2013, p. 1-6.

[22] Anuj, K., Yuvraj, S.N., Veena, C. and N.K. Bhardwaj, Characterization of cellulose nanocrystals produced by acid-hydrolysis from sugarcane bagasse as agro-waste. Journal of Materials Physics and Chemistry, 2014. 2(1): p. 1-8.

[23] Gao, X., Ke-Li, C., Heng, Z., Li-Cai, P. and L. Qi-Zing, Isolation and characterization of cellulose obtained from baggasse pith by oxygen-containing agents. BioResources, 2014. 9(3): p. 4094-4107.

[24] Ajit, M.K. and A.S. Padmakar, Determination of physico-chemical parameters of deoli bhorus dam water. Advances in Applied Science Research, 2012. 3(1): p. 273-279.

[25] Devangee, S., Kinjal, B., Jain, N.K. and H.A.. Modi, Physicochemical analysis of water from various sources and their comparative studies. Journal Of Environmental Science, Toxicology and Food Technology, 2013. 5(3): p. 89-92.

[26] Qureshimatva U. M., Maurya R. R., Gamit S. B., Patel R. D. and H.A. Solanki, Determination of physicochemical parameters and water quality index (wqi) of chandlodia lake, ahmedabad, gujarat, india. J. Environ Anal Toxicol., 2015. 5(4): p. 288.

[27] Zakari, M.A., Orukotan, A.A., Mohammed, S.S.D. and I.M. Aliyu, Microbiological analysis of baobab yoghurt produced using Lactobacillus bulgaricus. International Journal of Microbiology and Biotechnology, 2017. 2(2): p. 93-101.

[28] Robert, K., Kathleen, W-H. and R. Eric, Identifying unknown bacteria using biochemical and molecular methods credits: Developed and written by Kathleen Weston-Hafer. Specific protocols were optimized by Kathleen Weston-Hafer and Wilhelm Cruz. Washington University in support of Sarah C.R. Elgin from Howard Hughes Medical Institute (HHMI). ). 2006. p. 1-34.

[29] Kampfer, P., Nienhuser, A., Packroff, G., Wernicke, F., Mehling, A., Nixdorf, K., Fiedler, S., Kolauch, C. and M. Esser, Molecular identification of coliform bacteria isolated from drinking water reservoirs with traditional methods and the Colilert-18 system. Int. J. Hyg. Environ. Health, 2008. 211: p. 374-384.

[30] Tassadaq, H., Aneela, R., Shehzad, M., Iftikhar, A., Jafar, K., Veronique, E-H., Kil, Y.K. and A. Muhammad, Biochemical characterization and identification of bacterial strains isolated from drinking water sources of Kohat, Pakistan. African Journal of Microbiology Research, 2013. 7(16): p. 1579-1590.

[31] Pommet, M., Juntaro, J., Heng, J. Y., Mantalaris, A, Lee, A. F., Wilson, K., Kalinka, G., Shaffer, M.S. and A. Bismarck, Surface modification of natural fibers using bacteria: Depositing bacterial cellulose onto natural fibers to create hierarchical fiber reinforced nanocomposites. Biomacromolecules, 2008. 9(6): p. 1643-1651.

[32] WHO, Guidelines for drinking-water quality third edition incorporating the first and second addenda. Volume 1 Recommendations 3rd ed2008. Geneva. p. 1-668. 
[33] Anum, J., Almas, H., Nawshad, M., Ayesha, N., Moinuddin, G., Jibran, I., Sikander, R. and S.S. Noor, Cellulose-based materials for the removal of heavy metals from wastewater. ChemBioEng Rev., 2018. 4(4): p. 1-18

[34] Katrina, P.Y.S., Yean, L.P. and K.M. Shee, Nanocellulose: Recent advances and its prospects in environmental remediation. Beilstein J. Nanotechnol. 2018. 9: p. 2479-2498.

[35] WHO, Guidelines for drinking-water quality, 3rd ed2004; WHO, Geneva. p. 1-540.

[36] Nigerian Industrial Standard (NIS), Nigerian standard for drinking water quality approved by: SON Governing Council. NIS 554. 2007. p. 1-28.

[37] Henry, M. K., The national environment (standards for discharge of effluent into water or on land) regulations, S.I. No 5/1999 (Under section 26 and 107 of the National Environment Act, Cap 153). 1999. p. 1-4.

[38] Abdulmumini, A., Abubakar, I.T., Magaji, L., Sani, M.G., Ayuba, A.M., Shehu, H. and B.K. Isa, A Review on Industrial Effluents as Major Sources of Water Pollution in Nigeria. Chemistry Journal, 2015. 1(5): p. 159164

[39] Grace, O. C. O. and O. Patrick, Evaluation of some industrial effluents in Jos metropolis, Plateau State, Nigeria. African Journal of Environmental Science and Technology, 2015. 9(6): p. 566-572.

[40] Environmental Protection Agency (EPA), Parameters of water quality interpretation and standards published by the environmental protection agency, Ireland. 2001. p. 1-133.

[41] Yuhei, I. and F. Naoshi, Water quality and standards - II: Microbial/Biological contamination of water. Encyclopedia of Life Support Systems (EOLSS). 2002. P. 1-4.

[42] Iliyasu, A., Abdullahi, B. H. and A.H. Kawo, An assessment of the microbiological quality of some bottled water sold in Kano metropolis, Nigeria. Special Conference Edition, Bayero J. of Pure and Applied Sci., 2017. 10(1): p. 142-145.

[43] NAFDAC, Guidelines for registration of packaged water in Nigeria. Natioanl agency for drug administration and control: Decree no. 20 of 1999. 2004. p. 1-81.

[44] Megan, C., Joseph, G., Pramod, J., Avnish, K., Priyanshu, M., Peter, N., Mary, S., Rajnish, S., Ingrid, S., Dericks, S. and T. Seth, Designing a water filtration device to remove chemical and biological contamination in Mandi District. An interactive qualifying project submitted to the Faculty of Worcester Polytechnic Institute in partial fulfillment of the requirements for the degree of Bachelor of Science. 2018. p. 1-50.

[45] EPA 2003. US enviromental protection agency, safe drinking water act. EPA 816-F-03-016.

[46] Schwartz, J., Levin, R. and R. Goldenstein, Drinking water turbidity and gastrointestinal illness in the elderly of Philadelphia. J. Epidemiol. Comm. Hlth., 2000. 54: p. 45-51.

[47] John, K..N., Orish E.O. and O.E. Linus, Some physicochemical parameters of portable water supply in Warri, Niger Delta area of Nigeria. Science Resources and Essay, 2008. 3(11): p. 547-551. 
Azeh Yakubu, Yohanna Bello Paiko, and Gimba Alfred; One-Point Cellulose Adsorbents for Water Purification. Journal of Biomedical Engineering and Medical Imaging, Volume 6, No 4, Aug (2019), pp 1-15

[48] Adejuwon, J.O. and M. A. Adelakun, Physiochemical and bacteriological analysis of surface water in Ewekoro Local Government Area of Ogun State, Nigeria: Case study of Lala, Yobo and Agodo Rivers. International J. water Resources and Environment Engr., 2012. 4(3): p. 66-72.

[49] James, R.A.. Planning of wastewater reuse programme in Nigeria. Consilience: The Journal of Sustainable Development, 2016. 15(1): p. 1-33. 